\title{
Evaluation of Viral Migration of Different Variants of Equid Alphaherpesvirus 1 in the Central Nervous System of Hamsters by Immunohistochemistry
}

\author{
Aline Aparecida da Silva ${ }^{1}$, Elenice Maria Sequetin Cunha ${ }^{1}$, \\ Maria do Carmo Custódio de Souza Hunold Lara', Eliana Monteforte Cassaro Villalobos ${ }^{1}$, \\ Alessandra Figueiredo de Castro Nassar ${ }^{1}$, Enio Mori ${ }^{2}$, Carolina Natalia Zanuzzi ${ }^{3}$, \\ Cecília Mónica Galosi ${ }^{3}$, Claudia Del Fava ${ }^{1, *}$ \\ ${ }^{1}$ Biological Institute, Avenida Conselheiro Rodrigues Alves, São Paulo/SP, Brasil \\ ${ }^{2}$ Pasteur Institute, Avenida Paulista, São Paulo/SP, Brasil \\ ${ }^{3}$ Department of Histology and Embryology, Faculty of Veterinary Sciences, National University of La Plata, La Plata, Buenos Aires, Argentina \\ Email address: \\ alinesilvavet@gmail.com (A. A. da Silva), sequetin_cunha@hotmail.com (E.M. S. Cunha), \\ lara@biologico.sp.gov.br (M. do C. C. de S. Lara), villalobos@biologico.sp.gov.br (E. M. C. Villalobos), \\ nassar@biologico.sp.gov.br (A. F. de C. Nassar), emori@pasteur.saude.sp.gov.br (E. Mori), carozanuzzi@hotmail.com (C. N. Zanuzzi), \\ cmgalosi@hotmail.com (C. M. Galosi), delfava@biologico.sp.gov.br (C. D. Fava) \\ "Corresponding author
}

\section{To cite this article:}

Aline Aparecida da Silva, Elenice Maria Sequetin Cunha, Maria do Carmo Custódio de Souza Hunold Lara, Eliana Monteforte Cassaro Villalobos, Alessandra Figueiredo de Castro Nassar, Enio Mori, Carolina Natalia Zanuzzi, Cecília Mónica Galosi, Claudia Del Fava. Evaluation of Viral Migration of Different Variants of Equid Alphaherpesvirus 1 in the Central Nervous System of Hamsters by Immunohistochemistry. Animal and Veterinary Sciences. Vol. 7, No. 2, 2019, pp. 59-68. doi: 10.11648/j.avs.20190702.15

Received: March 12, 2019; Accepted: April 12, 2019; Published: June 13, 2019

\begin{abstract}
The intranasal inoculation of equid alphaherpesvirus1 (EHV-1) Brazilian variants A4/72, A9/92, A3/97, Iso72/10 and the Argentine variant AR4 in a Syrian hamster model Mesocricetus auratus induced severe encephalitis. Clinical signs included weight loss, lethargy, somnolence, anorexia, and intense salivation two days post-inoculation (dpi), followed by neurological signs such as loss of proprioception, walking in circles, spastic paralysis, seizures, recumbency and death at $3^{\text {rd }} \mathrm{dpi}$ (A9/92 and A4/72 variants) and $4^{\text {th }}$ dpi. Respiratory signs such as dyspnea and serosanguinous nasal discharge were also observed. Histopathological changes in brain included mixed inflammatory infiltrate with predominance of mononuclear cells, neuronal degeneration, liquefactive necrosis, hemorrhagic foci, leptomeningitis, perivascular edema, mononuclear infiltration, and perivascular cuffing. Immunohistochemical examination showed viral replication in neurons restrict predominantly to olfactory bulb and frontal cortex (variants AR4 and A3/97) and in groups of cells from distant regions, such as the caudal diencephalon and rostral mesencephalon (variants Iso72/10) and absence of viral antigen labeling of variants A9/92 and A4/72 despite these variants were the most neurovirulent, so new experiments not staggered in days but in hours post inoculation are needed to better understand the viral migration of these variants.
\end{abstract}

Keywords: EHV-1, Neurovirulence, Neuropathogenicity, Immunohistochemistry, Myeloencephalopathy

\section{Introduction}

Equid alphaherpesvirus1 (EHV-1) is an important pathogen endemic in equine populations worldwide, leading to significant losses due to respiratory disease, abortion, neonatal death, and myeloencephalopathy [1-3]. Equine herpesvirus myeloencephalopathy (EHM), classified as potentially emerging by the US Department of Agriculture [4-7], is a neurological dysfunction producing clinical signs ranging from proprioceptive deficiency, ataxia, limb weakness, swaying, stumbling, and falling to paralys is affecting mainly the hind limbs $[7,8]$. 
Necropsy shows brain congestion and focal areas of malacia or hemorrhage in the spinal cord and brain $[8,9]$. Histological changes in brain of horses infected with EHV-1 include vasculitis of small blood vessels or spinal cord with perivascular mononuclear and polymorphonuclear cuffing, degeneration of neurons, glial cell reaction, hemorrhagic foci, thrombosis with resulting ischemic neuronal necrosis, congestion, diffuse gliosis, perineuronal and perivascular edema [7, 10-12].

Studies of EHV-1 pathogenicity have usually employed murine and equine models [13-18]. However, studies involving adult horses are costly, labor intensive, and limited to a small number of animals [19]. Besides this experimentally inoculated horses may have antibodies to EHV-1 (immune memory) that can neutralize virus replication and, consequently, influence the type and magnitude of lesions produced and serological cross-reaction between EHV-1 and EHV-4 may interfere in the results [17].

Experiments using suckling Syrian hamsters have been conducted for virus isolation and studies of the pathogenesis of EHV-1 infection since the 1950s, when the detection of intranuclear inclusion bodies in the hepatic cells of hamsters inoculated intraperitoneally became possible [20]. Equid alphaherpesvirus 1 was first isolated in Brazil in the 1960s from a sample of aborted equine fetus liver inoculated intraperitoneally into suckling hamsters [1].

The first neurological signs of EHV-1 infection in suckling hamsters in Brazil were reported after intraperitoneal inoculation with a suspension of liver, spleen, and lung from an aborted equine fetus from Campinas, São Paulo [21]. The isolate, designated A4/72, was shown to cause tonic-clonic convulsions and paralysis in the infected hamsters. After the 1980s, isolation and study of EHV-1 in Brazil was accomplished predominantly via VERO cell culture and in equine dermal cells [22-24].

In subsequent years, the model of EHV-1 infection in hamster was used for the study of antiviral agents [25] and immune response to the virus [26, 27]. Recently, hamster models have been used to study the neuropathogenesis of EHV-9 [28-31], but there are few studies about neuropathogenicity of EHV-1 in hamster models [32].

With advances in molecular biology, hypotheses of the neuropathogenicity of EHV-1 have been proposed. Gene mutations of the open reading frame (ORF) 64, which encodes infected cell protein 4 , could be linked to neuropathogenicity [33].

A mutation exchanging adenine for guanine at position 2254 in ORF $30\left(\mathrm{~A}_{2254}-\mathrm{G}_{2254}\right)$ that leads to an alteration in the aminoacid 752 sequence (from $\mathrm{N}_{752}-\mathrm{D}_{752}$ ) is also linked to the neuropathogenicity of EHV-1, but only the amino acid variation $\mathrm{D}_{752}$ is linked to inflammation of the central nervous system and ataxia, while the $\mathrm{N}_{752}$ amino acid mutation is not shown to cause neurological signs in the natural host [34, 35].

Recent studies have shown that EHV-1 with ORF30 mutation $\left(\mathrm{N}_{752}-\mathrm{D}_{752}\right)$ did not lead to altered virus replication in FHK and mouse neuron cultured cells and residue 752 in the essential DNA Polymerase of EHV-1 was not required for virus growth [36]. The ORF37 (UL24) deletion has also been mentioned as a factor of lost of neuropathogenicity in a mouse model [37].

Despite the presented studies there is currently no consensus with respect to alterations that may make an EHV-1 variant neuropathogenic, so the aim of the present study was to characterize tissue damage and viral migration throughout the Central Nervous System of different variants of EHV-1 using a hamster model.

\section{Materials and Methods}

\subsection{Virus Variants}

The EHV-1 Brazilian variants A4/72, A9/92, Iso72/10, A3/97 (Rabies and Viral Encephalitis Laboratory, Biological Institute, SP, Brazil) [21, 23, 38] and AR4 Argentine variant isolated from aborted equine fetuses were used in this study $[39,40]$. All isolates were confirmed to be EHV-1 by PCR amplification and DNA sequencing of the unique transcriptional regulator genes (Brazilian variants: GenBank accession number EU094655 to EU094657; Argentine variant: GenBank accession number EU366295).

The A9/92 ( $6^{\text {th }}$ passage) and A4/72 (21 ${ }^{\text {th }}$ passage) viruses were propagated in VERO cells, A3/97 ( $5^{\text {th }}$ passage $)$ and Iso $72 / 10\left(1^{\text {st }}\right.$ passage $)$ in ED cells and AR4 ( $2^{\text {nd }}$ passage) in RK-13 cells. Cell lines were grown in Eagle's Minimum Essential Medium (EMEM) supplemented with $10 \%$ fetal calf serum. After three cycles of freezing and thawing, the cells and infectious supernatant were centrifuged at $8000 \times \mathrm{g}$ for 20 min to remove cell debris. The final infectious supernatant was fractionated into small volumes and stored at $-70^{\circ} \mathrm{C}$ until use [8].

\subsection{Experimental Animals}

Twenty-four Syrian hamsters Mesocricetus auratus were obtained from the animal facility of the Department of Pathology, School of Veterinary Medicine and Animal Science, University of SãoPaulo, SãoPaulo, Brazil. Hamsters were separated into six groups, five experimental and an untreated control, with groups housed separately in polycarbonate micro-isolator cages, each connected to an individual ventilation system with HEPA filters on both the in- and out- flow. Filtered and autoclaved water and commercial pellets were provided ad libitum. All procedures were approved by the Ethics Committee on Animal Experiments of the Biological Institute (CETEA-IB) on registration protocol number CETEA-IB 106/10.

Five groups of four 3-week-old male hamsters, 40-50g, were anesthetized with inhaled Sevoflurane (Sevocris ${ }^{\circledR}$, Cristália, Itapira, SP) and inoculated intranasally with 50 $\mu$ l EMEM containing $10^{4} \mathrm{TCID}_{50}$ of one of the following variants of EHV-1: A4/72, A9/92, A3/97, Iso72/10 and AR4. A negative control group comprised four female 3-week-old Syrian hamsters, 40 $50 \mathrm{~g}$, inoculated intranasally with $50 \mu 1$ non-infected EMEM.

After inoculation, the infected hamsters were weighed and evaluated twice daily to register of clinical signs that were recorded as absent, slight, moderate or severe by the same 
operator of the experiment. At the onset of severe clinical signs they were euthanized along with the control group by an overdose of Sevoflurane and necropsied to collect samples of brain, lung, spleen, liver, thymus, heart, and kidney [18].

\subsection{Histopathology}

The collected organs were fixed for $48 \mathrm{~h}$ in $10 \%$ buffered formalin then transferred to $70 \%$ ethanol, dehydrated in ethanol series, cleared in xylene, and embedded in paraffin. Sections were cut at $3 \mu \mathrm{m}$, deparaffinized, rehydrated, and stained with $\mathrm{H} \& \mathrm{E}$ [11]. The histological score was classified in absent, slight, moderate or severe according to the intensity of microscopical lesions by the same pathologist of the experiment.

\subsection{Immunohistochemistry}

Sections of organs were dewaxed in xylol at $37^{\circ} \mathrm{C}$ for $30 \mathrm{~min}$, and endogenous peroxidase was blocked in a solution of $20 \mathrm{ml}$ of $30 \%$ hydrogen peroxide $\left(\mathrm{H}_{2} \mathrm{O}_{2}\right)$ diluted in $80 \mathrm{ml}$ of methanol for $30 \mathrm{~min}$. Antigen retrieval was performed with citrate buffer $(\mathrm{pH}$ 6.0 ) by heating in a microwave oven ( $1000 \mathrm{~W}$ for $15 \mathrm{~min})$ prior to incubation with the primary antibody in a humid chamber at $37^{\circ} \mathrm{C}$ for $30 \mathrm{~min}$ with a $1: 1000$ dilution of goat antiserum specific for ERV/EHV-1 (VMRD ${ }^{\circledR}$ USA Inc. catalog 210-70-ERV, Pullman, Washington, USA). Finally, they were incubated with streptavidin-biotin complex (a combination of anti-mouse, -rabbit, and -goat immunoglobulins; LSAB+System-HRP, Dako $^{\circledR}$ ref. K0690-Dako ${ }^{\circledR}$ Cytomation, Carpinteria, California, USA) for $45 \mathrm{~min}$ in a humid chamber at room temperature. The reaction was revealed upon exposure to 3,3 ' diaminobenzidine chromogen solution (DAB, Dako ${ }^{\circledR}$ code ref K3468). The slides were counterstained with Mayer's hematoxylin and mounted with synthetic resin (Entellan-Merck ${ }^{\circledR}$ ) [11]. The presence of viral antigen was classified in: -absent when no antigen was stained; + few when found less than 5 stained cells in $40 \mathrm{x}$ field; ++ moderate when found 5-30 stained cells in $40 \mathrm{x}$ field or +++ numerous when found more than 30 stained cells in $40 \mathrm{x}$ field according to the evaluation of the same pathologist of the experiment.

\section{Results}

\subsection{Clinical Signs}

The hamsters inoculated with the A/92 and A4/72 variants presented high weight loss at 2 days post-inoculation (dpi), with severe disease at 3 dpi characterized by intense salivation and neurological signs such as loss of proprioception, walking in circles, spastic paralysis, seizures, and recumbency, followed by death. Those inoculated with the Iso $72 / 10$ variant showed similar neurological signs, but the acute phase started at 4 dpi and included respiratory signs such as dyspnea and serosanguinous nasal discharge.

Animals inoculated with A3/97 and AR4 variants showed weight loss, lethargy, somnolence, and respiratory signs, predominately dyspnea and serosanguinous nasal discharge. At 4 dpi, the hamsters exhibited neurological signs such as hyperexcitability in response to external stimuli, tremors, and seizures, but effects were less severe than observed with the other studied variants. The control group showed normal weight gain and did not exhibit behavior, respiratory, or neurological abnormalities (Figure 1; Table 1).

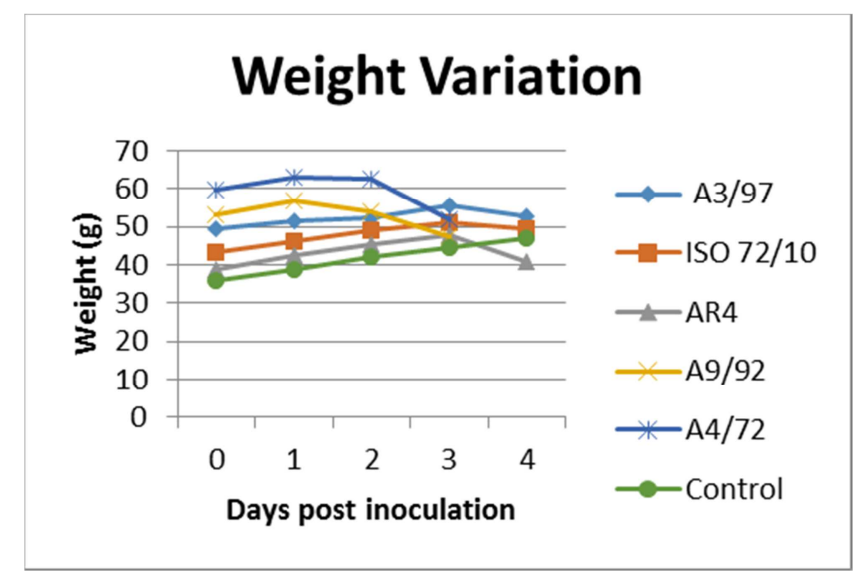

Figure 1. Weight variation of hamsters intranasaly inoculated with five variants of EHV-1, 0-4 days post-inoculation.

Table 1. Clinical signs linked to CNS damage in hamsters after inoculation with five EHV-1variants.

\begin{tabular}{|c|c|c|c|c|c|}
\hline Clinical Signs & A9/92 & A4/72 & ISO72/10 & $\mathbf{A} 3 / 97$ & AR4 \\
\hline Anorexia & $+++*$ & +++ & ++ & ++ & ++ \\
\hline Lethargy & +++ & +++ & ++ & ++ & ++ \\
\hline Weight loss & +++ & +++ & + & + & ++ \\
\hline Nasal discharge & - & - & +++ & +++ & +++ \\
\hline Dyspnea & - & - & +++ & ++ & +++ \\
\hline Tremors & +++ & +++ & +++ & ++ & - \\
\hline Intense salivation & +++ & +++ & +++ & +++ & ++ \\
\hline Ataxia & +++ & ++ & + & - & - \\
\hline Spastic paralysis & ++ & ++ & - & - & - \\
\hline Walking in circles & +++ & ++ & - & - & - \\
\hline Hypersensitivity to external stimulus & +++ & +++ & +++ & ++ & + \\
\hline Seizures & +++ & +++ & +++ & ++ & - \\
\hline
\end{tabular}

* Intensity of clinical signs: (-) absent, $(+)$ slight, $(++)$ moderate, $(+++)$ severe. 


\subsection{Pathological Findings}
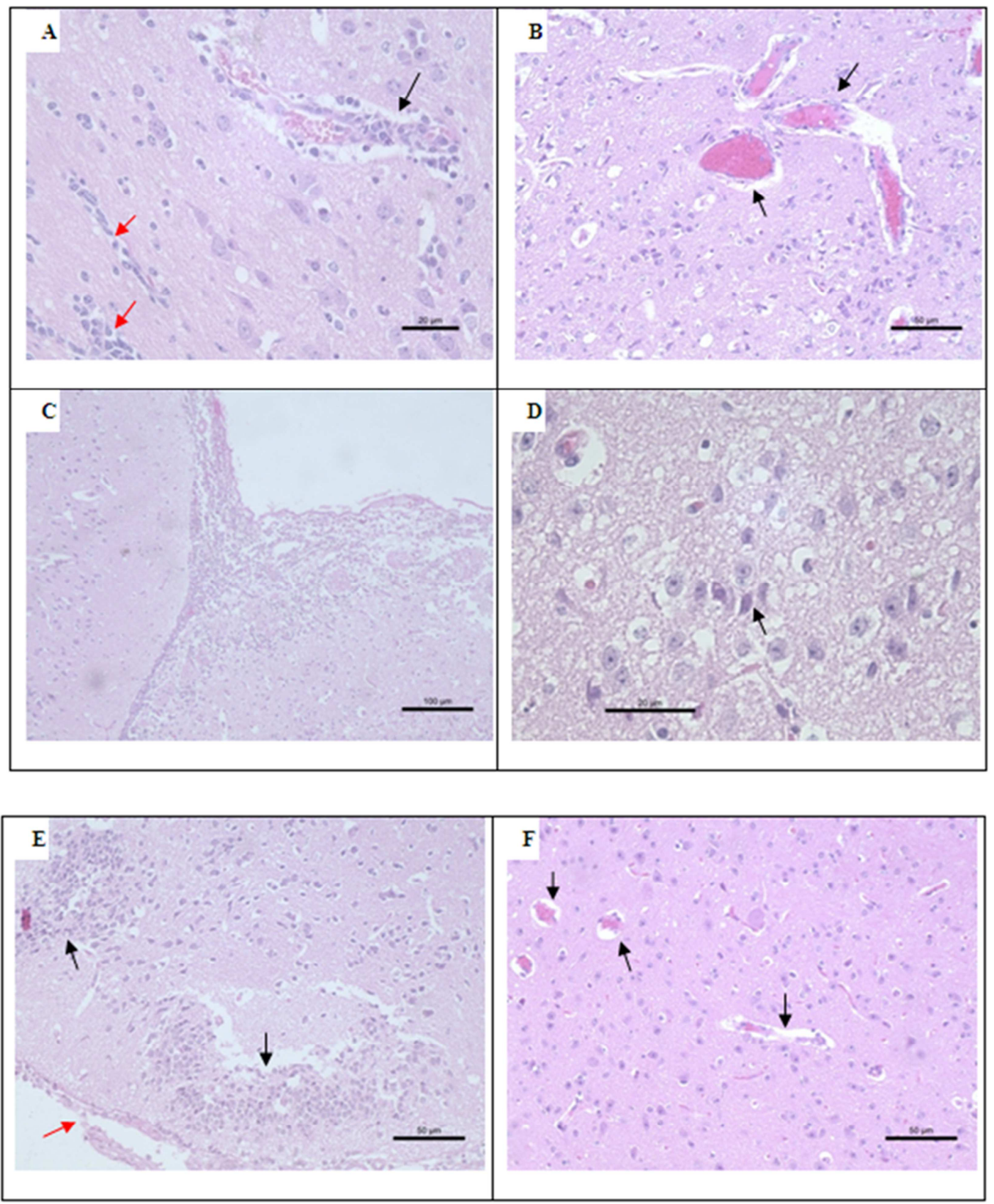

Figure 2. Brain; Cortex region of hamsters experimentally intranasally infected with equid alphaherpesvirus type 1 variants. (a) Iso72/10 variant; mononuclear perivascular cuff (arrow) and mononuclear foci (red arrow) (Bar20 $\mathrm{mm}$ ). (b) Iso72/10 variant; diffuse expansion of the meninges with a large number of

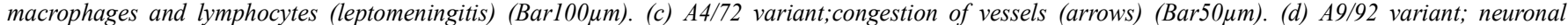

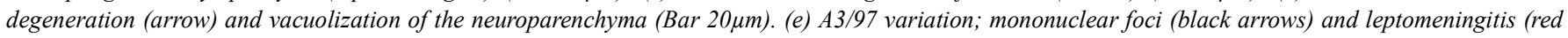

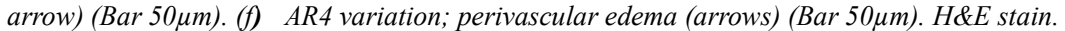

Table 2. Histopathological changes observed in the CNS of hamsters inoculated with five EHV-1 variants.

\begin{tabular}{|c|c|c|c|c|c|}
\hline Microscopic lesions in CNS (Histopathology) & A9/92 & A4/72 & ISO72/10 & A3/97 & AR4 \\
\hline Inflammatory infiltrate areas & $++^{*}$ & ++ & +++ & +++ & +++ \\
\hline Leptomeningitis & ++ & ++ & +++ & ++ & ++ \\
\hline Hemorrhagic foci & ++ & + & + & - & - \\
\hline Neuronal degeneration & +++ & +++ & ++ & ++ & ++ \\
\hline Liquefactive necrosis & +++ & ++ & ++ & + & + \\
\hline Intranuclear inclusion body & + & - & - & - & - \\
\hline Neuropil edema & +++ & +++ & ++ & + & + \\
\hline
\end{tabular}

* Intensity of microscopic lesions: $(-)$ absent, $(+)$ slight, $(++)$ moderate, $(+++)$ severe. 
The lungs were edematous and did not collapse upon opening of the thoracic cavity. They presented diffuse reddish coloration in the pulmonary lobes corresponding to hemorrhagic areas. The histological examination showed intense and diffuse mixed inflammatory infiltrate with predominance of mononuclear cells, areas of moderate to intense congestion, hemorrhagic foci, thickened alveolar walls, moderate to intense foamy macrophage infiltration in the alveolar lumen, presence of free red blood cells and alveolar edema, intact bronchiolar epithelium, and slight to moderate mucous secretion. The pleura showed discrete swelling and moderate emphysema.

Cellular debris and free red blood cells in the bronchiolar lumen were observed in hamsters inoculated with the A9/92 and AR4 variants. In hamsters inoculated with Iso 72/10 and AR4 variants, syncytia and intranuclear inclusion bodies were observed in the parenchyma. No alterations were found in spleen, liver, thymus, kidney, or heart of inoculated hamsters. No macroscopic or histological changes were observed in any organ of the control group.

\subsection{Immunohistochemistry}

Positive immunohistochemical labeling was found in a group of neurons from a necrotic foci in the frontal pole region of hamsters inoculated with A4/72. The hamsters inoculated with Iso $72 / 10$ presented immunolabeling in neurons of the olfactory bulb and in groups of cells of the caudal diencephalon and rostral mesencephalon (Figure 3a, b).

The hamsters inoculated with A3/97 and AR4 variants showed positive immunolabeling only in the olfactory bulb region (internal granule cells) and in groups of neurons of the frontal pole cortex (Figure $3 \mathrm{c}, \mathrm{d}$ ). The meninges and other areas of the CNS such as striated septum, pons, and medulla oblongata showed no positive labeling with any variant (Table 3). No immunoreactivity was observed in the organs of hamsters inoculated with A9/92 variant and from negative control group.

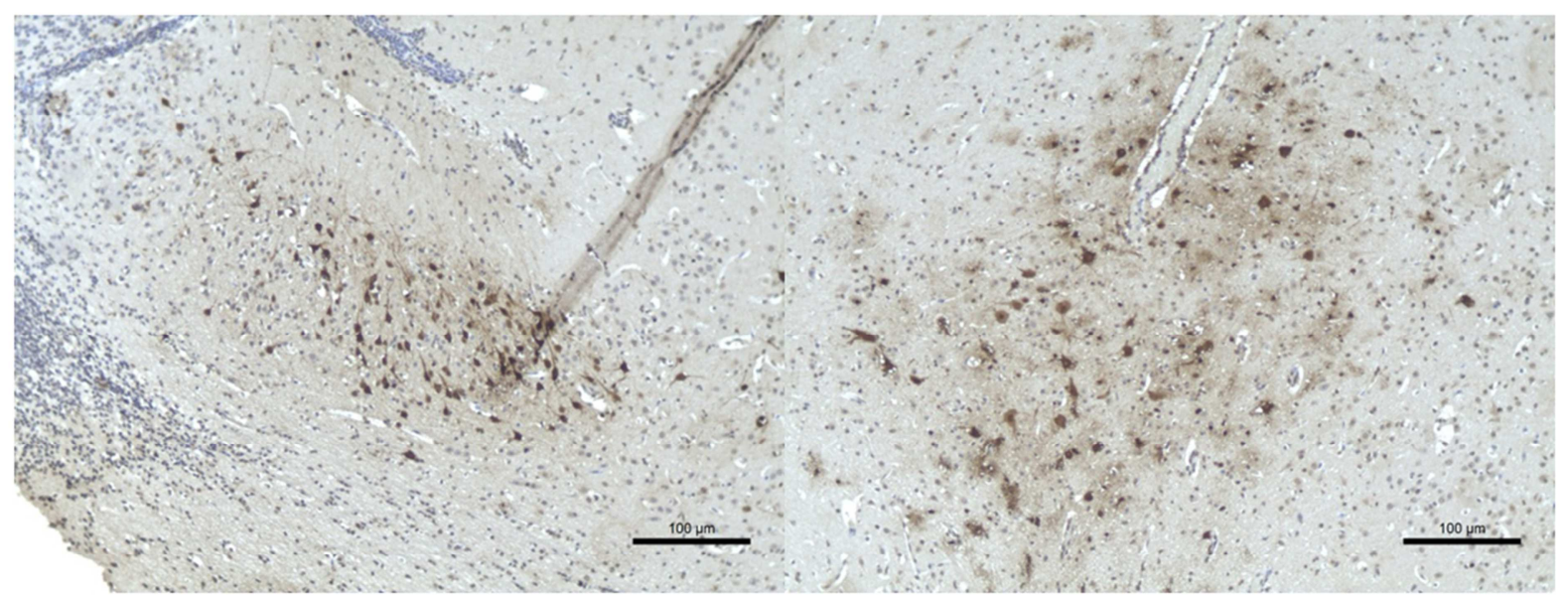

(a)

(b)

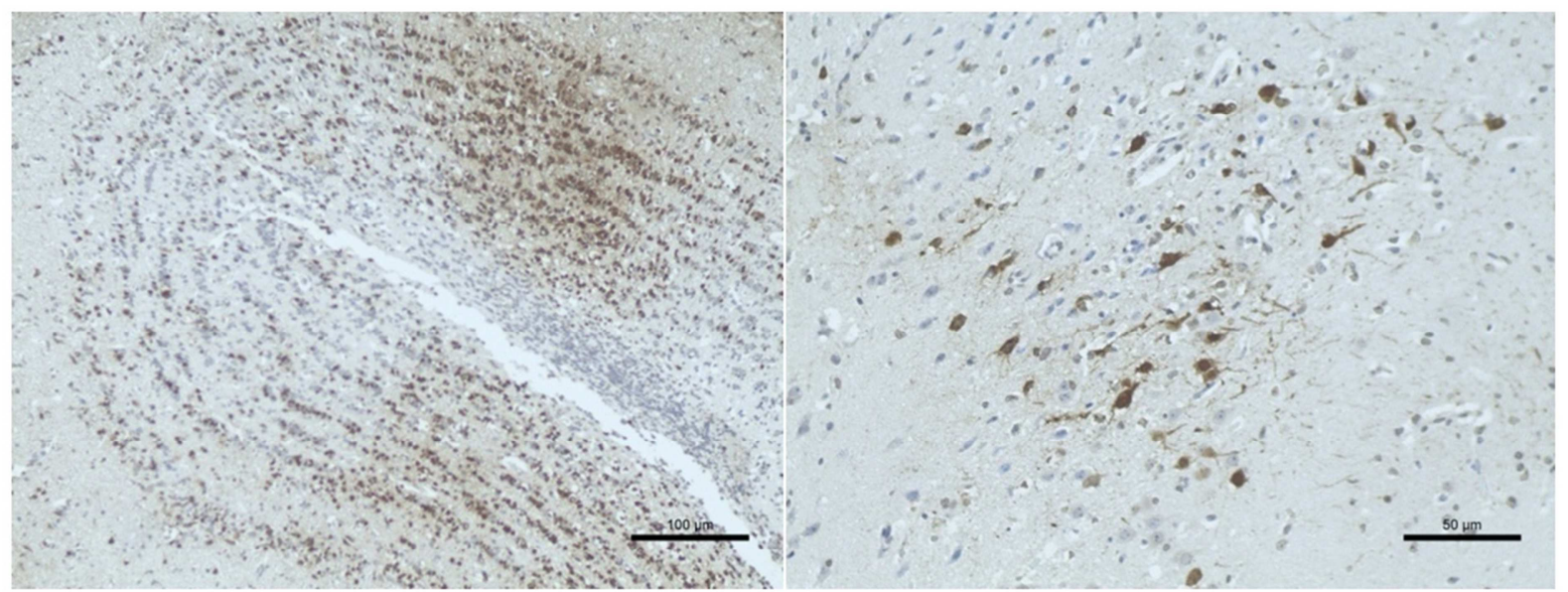

(c)

(d)

Figure 3. Brain of hamsters intranasally infected with equid alphaherpesvirus type1 variants. (a) Iso $72 / 10$ variant; frontal cortex region with many neurons

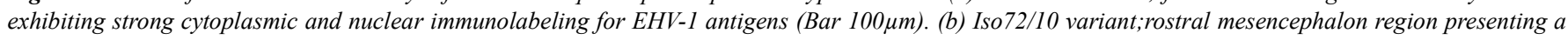
group of neurons exhibiting strong cytoplasmic and nuclear immunolabeling for EHV-1 antigens (Bar 100 $\mu$ ). (c) A3/97 variant; olfactory bulb region with internal granule cells exhibiting strong cytoplasmic and nuclear immunolabeling for EHV-1 antigens (Bar 100 $\mu m$ ). (d) A3/97 variant; frontal pole region with groups of neurons exhibiting strong cytoplasmic and nuclear immunolabeling for EHV-1 antigens (Bar 50 $\mathrm{um}$ ). Immunohistochemistry for EHV-1. 
Table 3. Viral detection by immunohistochemistry in brain of hamsters intranasally inoculated with five EHV-1 variants.

\begin{tabular}{lllll}
\hline \multirow{2}{*}{ Brain Region } & \multicolumn{2}{l}{ Viral detection of EHV-1 by IHC } & & A3/97 \\
\cline { 2 - 5 } & A9/92 & A4/72 & ASO72/10 & - \\
\hline Meninges & $-*$ & - & - & - \\
Olfactory bulb & - & - & +++ & +++ \\
Frontal pole & - & + & +++ & ++ \\
Striated septum & - & - & - & - \\
Caudal diencephalon & - & - & + & - \\
Rostral mesencephalon & - & - & - & - \\
Pons and medulla oblongata & - & - & - & - \\
\hline
\end{tabular}

*Presence of viral antigen: -absent; +few (<5/40xfield); ++moderate (5-30/40xfield); +++numerous ( $>30 / 40 x$ field).

\section{Discussion}

The neurological signs observed in hamsters inoculated with the EHV-1 variants tested were similar to those described after natural infection in the host equine species: lethargy, anorexia, and ataxia reaching peak intensity at 2-3 dpi [41-43]. Meningeal congestion was the only macroscopic alteration in brain of the inoculated hamsters, this alteration has also been observed in mice and horses as a result of EHM, associated with congestion and hemorrhagic foci in spinal cord [7, 8, 18].

The microscopic lesions were similar to those reported in hamsters infected with EHV-9 and in mice and hamsters inoculated with EHV-1, with the olfactory bulb and frontal cortex being the primary affected regions after intranasal inoculation $[8,16,28,29,31,32]$. In hamster and murine models, the intranasally inoculated virus migrates from the nasal mucosa by neural dissemination via the olfactory neuroepithelium throughout the olfactory bulb, olfactory nerve, and ventricular surface, leading to neuronal degeneration, mainly in cortical areas and the hippocampus, with associated generalized ventriculitis $[16,18,28,30]$.

As reported by other authors, we also found variation in severity of clinical signs, according the pathogenicity of the virus variant $[15,30]$. Variants $A 9 / 92$ and A4/72 showed high neurovirulence, compared to the other tested variants, with results similar to those reported in mice after intranasal inoculation [18]; the Iso $72 / 10$ variant showed lighter neurological signs with acute phase starting only at $4 \mathrm{dpi}$ and presented also respiratory signs while A3/97 and AR4 variants caused predominantly respiratory signs [32]. In a study using several line ages of mice, the A3/97 variant caused no weight loss or apparent clinical signs of disease, although it was possible to recover the virus from lung of all infected mice and from brain of a single BALBc nude mouse [18].

Hamsters infected with Iso/72, A3/97 and AR4 presented CNS lesions predominantly inflammatory (meningo-encephalitis) while hamsters inoculated with A4/72 and A9/92 showed predominantly neuronal necrosis with vacuolization of the neuroparenchyma, perineuronal and perivascular edema, with liquefactive necrosis in many areas of the CNS instead of inflammatory changes [32].

In adult horses, EHM induces microvascular damage to the central nervous system via initiation of an inflammatory cascade followed by degenerative thrombotic vasculitis of small blood vessels in the brain or spinal cord with resultant ischemic neuronal necrosis, perivascular mononuclear cuffing, congestion, hemorrhage, diffuse gliosis, perineuronal and perivascular edema $[7,12,44]$. In hamsters is suggested that these lesions may be the result of the viral replication within neurons, as opposed to vascular changes [32].

Effects of the less pathogenic EHV-1 variants have been reported to remain confined to the olfactory bulb region, while the more virulent variants migrates via neurons throughout the brain by anterograde axonal transport and slow axonal flow, infecting neurons and causing severe tissue damage throughout the CNS [16]. In contrast, in the present study, one less neuropathogenic variant (Iso72/10) were immunohistochemically detected even in distant regions from the olfactory bulb such as caudal diencephalon and rostral mesencephalon, while A4/72 one of the more virulent variant were detected only in a group of cells of necrotic area from the frontal pole region, so further studies are needed to better understand EHV-1 migration.

The route of inoculation seems to be an important factor in the development and progress of experimental herpes infection and migration. In a study of EHV-9, clinical signs of encephalitis including salivation, tremors, uncoordinated movement, convulsions, and severe moribund states were present in $100 \%$ of hamsters intranasally inoculated but in only $25 \%$ of those inoculated by oral and peritoneal routes [30]. On the other hand, noneurological signs were observed in hamsters inoculated via intravenous or ocular routs [30].

The time course of infection in hamsters seems also to be important in the migration of the herpes virus throughout the CNS. EHV-9 viral antigens were detected in the olfactory epithelium, nerve and bulb in the first 48 hours post inoculation, while in the cerebral cortex and areas such as those connecting the trigeminal sensory nerve root to the brain stem, pons and medulla oblongata, positive detection was found at 60h PI [29]. Recent studies in mice have shown the EHV-1 and 9 migration from the olfactory epithelium to the olfactory bulb on day 3 post inoculation, but without viral migration to other areas of the CNS, probably due to the higher susceptibility to infection of the hamster in comparison to mice $[16,45]$.

The dose of the inoculums and the type of anesthetic used must also be considered in pathogenicity and virulence studies. Intranasal inoculation of hamsters with EHV- 9 at $10^{1}$ PFUs was reported to not cause death, whereas with $10^{4}$ PFUs, hamsters became severely ill at 3 dpi and died at 4 dpi [28]. In a study with mice intranasally inoculated with EHV-1 (AR4 variant) it was observed that clinical signs were more severe in 
animals anesthetized with ether; ketamine/xylazine anesthetized animals presented the highest cell death rates, while those anesthetized with isoflurane showed the highest proliferation rates, despite this isoflurane was considered a good anesthetic for experimental assays, since it produced few known side effects, animal suffer and showed a better post anesthesia recovery [46].

Studies have suggested that genotype alterations may be responsible for EHV-1 neuropathogenicity. EHV-1 variants with the exchange of adenine for guanine at position 2254 in ORF30 $\left(\mathrm{A}_{2254}-\mathrm{G}_{2254}\right)$, leading to alteration in the aminoacid 752 sequence (from $\mathrm{N}_{752}-\mathrm{D}_{752}$ ), have been associated with the potential to cause neurological disease. This genotype alteration was associated with 30 of 32 outbreaks of neurological disease for EHV-1 in 2001-2006 in United Kingdom and United States [34, 47].

Prevalence of EHV-1 variants considered neuropathogenic $\left(\mathrm{G}_{2254} / \mathrm{D}_{752}\right)$ increased from $3.6 \%$ in the 1960 s to $13.3 \%$ in the $1990 \mathrm{~s}$ in central Kentucky's thoroughbred broodmare population [19]. This number increased to $19.4 \%$ in 2000 2006 , suggesting that viruses of the neuropathogenic genotype were increasing in prevalence in the latent reservoir, leading to greater risk of outbreak of equine herpesvirus neurological disease [19].

The amount of EHV-1 nasal shedding significantly increased in animals infected with the $\mathrm{D}_{752}$ variant compared with $\mathrm{N}_{752}$ variant ( $\mathrm{p}=0.001$ ); the $\mathrm{D}_{752}$ variant led, on average, to a four-fold higher amount of nasal EHV-1 shedding compared to infections with the $\mathrm{N}_{752}$ variant, suggesting that neuropathogenic variants could have a selective advantage and are systematically increasing in prevalence in domestic horse populations [48].

A experiment comparing the partial nucleotide sequences of ORF72 (glycoprotein D-gD), ORF64 (ICP4), and ORF30 (DNA polymerase) genes to corresponding sequences of EHV-1, found that the reference variant showed no molecular variation in the ICP4, gD, or viral DNA polymerase gene regions from the evaluated variants, in the experimental the EHV-1 Brazilian variants analyzed, including A3/97, A4/72, and $A 9 / 92$, were classified as non-neuropathogenic variants $\left(\mathrm{N}_{752}\right)$ based on the ORF30 analysis, suggesting that other factors, such as the immuneresponse of the host species, could be involved in EHV-1 neuropathogenicity [49].

We found Brazilian (A4/72, A3/97, A9/92, Iso72/10) and Argentine (AR4) variants to demonstrate neurotropism and neurovirulence, and were capable of causing neurological disorders and acute brain lesions (cell death and diffuse encephalitis) of inoculated hamsters, despite their classification as non-neuropathogenic variants [40, 49]. Mice inoculated with an EHV-1 mutant variant $(\mathrm{Ab} 4 \mathrm{p} \Delta \mathrm{ORF} 37)$ in which ORF37 was deleted, did not show neurological symptoms, death and body weight loss indicating that ORF37 may be one of the neuropathogenicity factors of EHV-1 [37].

Recent studies have shown neuropathogenic variants $01 \mathrm{c} 1$ to exhibit growth kinetics similar to those of non-neuropathogenic variants in fetal horse kidney and cultured neurons and suggest that the $\mathrm{D} / \mathrm{N}_{752}$ dissimilarity in
ORF30 may not be related to replication ability in fetal horse kidney and neural cell lines [36].

In a study to evaluate the ability of neuropathogenic (EHV-1) and non-neuropathogenic (Jan-E and Rac-H) EHV-1 variants to infect neuronal cells, real-time PCR analysis demonstrated that both neuropathogenic and non-neuropathogenic EHV-1 variants replicated in primary murine neurons and ED cells at a similar level [50].

Analyzed together, these data reinforcing the hypothesis that factors other than only a specific genotype mutation can also be involved in the neuropathogenicity of EHV-1, such as innate response, glycoproteins (gI, gE) and different cellular immune markers, including alpha-interferon (IFN- $\alpha$ ), gamma-interferon (IFN- $\gamma$ ), interleukin-10 (IL-10) and interleukin-1 beta (IL-1 $\beta$ ) that were identified to play a role during the course of the disease in experimental animal models [19, 37, 50-55].

\section{Conclusions}

The five EHV-1 variants tested induced severe encephalitis in the hamster model; viral replication in neurons restrict predominantly to olfactory bulb and frontal cortex were observed in variants AR4 and A3/97, more related with respiratory clinical signs than neurological; while the variant Iso $72 / 10$, related to both neurological and respiratory signs presented migration in groups of cells of caudal diencephalon and rostral mesencephalon and the most neurovirulent strains A9/92 and A4/72 presented no labeling, suggesting that further studies, not staggered in days but in hours post inoculation, are needed to better understand the viral migration of these neurovirulent variants.

\section{Acknowledgements}

This study was supported by funding from the Fundação de Amparo à Pesquisa do Estado de SãoPaulo, Brasil (FAPESP), Research Assistance number 2012/00277-0 and scholarship from the Coordenação de Aperfeiçoamento de Pessoal de Nível Superior, Brasil (CAPES), Finance Code 001.

\section{Conflicts of Interest}

The authors declare no conflict of interest.

\section{References}

[1] Nilsson, M. R.; Corrêa, W. M. Isolamento do vírus do aborto eqüino no Estado de São Paulo. Arq. Inst. Biol. 1966, 33, 23-25.

[2] Laugier, C.; Foucher, N.; Sevin, C.; Leon, A.; Tapprest, J. A 24-Year Retrospective Study of Equine Abortion in Normandy (France). J. Equi. Vet. Sci. 2011, 31, 116-123; DOI: org/10.1016/j.jevs.2010.12.012.

[3] Dunowska, M. A review of Equid herpesvirus 1 for the veterinary practitioner. Part A: clinical presentation, diagnosis and treatment. N. Z. Vet. J. 2014, 62, 171-178. 
[4] APHIS (2007). Equine herpesvirus myeloencephalopathy: A Potentially Emerging Disease. Available on line: $<$ https://www.aphis.usda.gov/animal health/emergingissu es/downloads/ehv1 final.pdf $>$. (Accessed on 04 January 2016).

[5] Lara, M. C. C. S. H.; Cunha, E. M. S.; Villalobos, E. M. C.; Nassar, A. F. C.; Asano, K. M.; Fernandes, W. R.; Richtzenhain, L. J.; Brandão, P. E.; Mori, E. First isolation of equine Herpesvirus type 1 from a horse with neurological disease in Brazil. Arq. Inst. Biol. 2008, 75, 221-224.

[6] Vandekerckhove, A. P.; Glorieux, S.; Gryspeerdt, A. C.; Steukers, L.; Duchateau, L.; Osterrieder, N.; Van De Walle, G. R.; Nauwynck, H. J. Replication kinetics of neurovirulent versus non-neurovirulent equine herpesvirus type 1 strains in equine nasal mucosal explants. J. Gen. Virol. 2010, 91, 2019-2028; DOI: 10.1099/vir.0.019257-0.

[7] Mori, E.; Borges, A. S.; Delfiol, D. J. Z.; Oliveira Filho, J. P.; Gonçalves, R. C.; Cagnini, D. Q.; Lara, M. C. C. S. H.; Cunha, E. M. S.; Villalobos, E. M. C.; Nassar, A. F. C.; Castro, A. M. M. G.; Brandão, P. E.; Richtzenhain, L. J. First detection of the equine herpesvirus 1 neuropathogenic variant in Brazil. Rev. Sci. Tech. Off. Int. Epiz. 2011, 30, 949-954.

[8] Allen, G. P.; Kydd, J. H.; Slater, J. D.; Smith, K. C. Equid herpesvirus-1 (EHV-1) and -4 (EHV-4) infections. In: Infectious Diseases of Livestock, 2ed. Oxford, 2004; pp 829-859.

[9] Wilson, W. D. Equine herpesvirus 1 myeloencephalopathy. Vet. Clin. North America Equi. Practice. 1997, 13, 53-72.

[10] Schultheiss, P. C.; Collins, J. K.; Hotaling, S. Immunohistochemical demonstration of Equine Herpesvirus-1 antigen in neurons and astrocytes of horses with acute paralysis. Vet. Pathol. 1997, 34, 52-54.

[11] Silva, A. A., Cunha, E. M. S., Lara, M. C. C. S. H., Villalobos, E. M. C., Nassar, A. F. C., Mori, E., Zanuzzi, C. N., Galosi, C. M., and Del Fava, C. Arq. Inst. Biol., 2018, 85, 1-7.

[12] OIE (World Organization For Animal Health) (2015). Equine rhinopneumonitis. OIE Terrestrial Manual. Chapter 2.5.9. p. 897. Available online: $<\mathrm{http} / / \mathrm{www}$.oieint/fileadmin/Home/eng/Health standa rds/tahm/2.05.09_EQUINE_RHINO.pdf $>$. (Accessed on 04 August 2016).

[13] Awan, A. R.; Chong, Y. C.; Field, H. J. The pathogenesis of equine herpesvirus type 1 in the mouse: a new model for studying host responses to the infection. J. Gen. Virol. 1990, 71, 1131-1140.

[14] Gibson, J. S.; Slater, J. D.; Awan, A. R.; Field, H. J. Pathogenesis of equine herpesvirus-1 in specific pathogen-free foals: primary and secondary infections and reactivation. Arch. Virol. 1992, 123, 351-366.

[15] Hasebe, R.; Kimura, T.; Sato, E.; Okazaki, K.; Ochiai, K.; Wada, R.; Ememura, T. Equine herpesvirus-1 induced encephalomyelitis in mice: a comparative study of neuroadapted virus and its parental strain. J. Comp. Path. 2002, 127, 118-125.

[16] Gostonyi, G.; Borchers, K.; Ludwig, H. Pathogenesis of equine herpesvirus-1 infection in the mouse model. APMIS - Acta Path. Microbiol. Immunol. Scandinava. 2009, 117, 10-21; DOI: 10.1111/j.1600-0463.2008.00008.x.

[17] Mori, E.; Mori, C. M. C.; Massironi, S. M. G.; Cunha, E. M. S.;
Villalobos, E. M. C.; Lara, M. C. C. S. H.; Fernandes, W. R. Detection of equid herpesvirus 1 DNA by Polymerase Chain Reaction after experimental inoculation of horses with a Brazilian A4/72 strain. Braz. J. Vet. Res. Anim. Sci. 2009, 46, 253-261.

[18] Mori, C. M. C.; Mori, E.; Favaro, L. L.; Santos, C. R.; Lara, M. C. C. S. H.; Villalobos, E. M. C.; Cunha, E. M. S.; Brandão, P. E.; Richtzenhain, L. J.; Maiorka, P. C. Equid Herpesvirus type-1 exhibits neurotropism and neurovirulence in a mouse model. J. Comp. Path. 2012, 146, 202-210; DOI: 10.1016/j.jcpa.2011.04.003.

[19] Smith, K. L.; Allen, G. P.; Branscum, A. J.; Frank Cook, R.; Vickers, M. L.; Timoney, J. P.; Balasuriya, U. B. R. The increased prevalence of neuropathogenic strains of EHV-1 in equine abortions. Vet. Microbiol. 2010, 141, 5-11; DOI: 10.1016/j.vetmic.2009.07.030.

[20] Doll, E. R.; Richards, M. G.; Wallace, M. E. Adaptation of the equine abortion virus to suckling Syrian hamsters. Cornell Vet. $1953,43,551-558$.

[21] Reiner, U. R.; Lucca Neto, D.; Nilsson, M. R.; Nilsson, T. T.; Kotait, I. Isolamento do vírus do aborto eqüino em Campinas, Estado de São Paulo. In: Congresso Brasileiro de Medicina Veterinária, 13, Brasília. Anais... Brasília: Associação Brasileira de Medicina Veterinária, 1972.

[22] Kotait, I. Herpesvírus eqüino tipo 1: incidência e diagnóstico laboratorial. Rev. Bras. Reprod. Ani. 1991, 1, 164-171.

[23] Cunha, E. M. S.; Peixoto, Z. M. P.; Kroeff, S. S.; Queiroz, L. H.; Kotait, I. Isolamento e identificação do herpesvirus eqüino tipo 1 (EHV-1): confirmação do diagnóstico clínico. In: Reunião Anual do Instituto Biológico, 6 ed, São Paulo, 1993; 15.

[24] Carvalho, R. F.; Spilki, F. R.; Cunha, E. M. S.; Stocco, R. C.; Arns, C. W. Molecular data of UL24 homolog gene (ORF37) from Brazilian isolates of equine herpesvirus type 1. Res. Vet. Sci. 2012, 93, 494-497.

[25] Rollinson, E. A.; White, G. Relative activities of acyclovir and BW759 against Aujeszky's disease and equine rhinopneumonitis viruses. Antimicrob. Agents Chemother. 1983, 24, 221-226.

[26] Stokes, A.; Allen, G. P.; Pullen, L. A.; Murray, P. K. A hamster model of Equine Herpesvirus Type 1 (EHV-I) infection: passive protection by monoclonal antibodies to EHV-1 glycoproteins 13/14 and 17/18. J. Gen. Virol. 1989, 70, 1173-1183.

[27] Tsujimura, K.; Yamanaka, T.; Kondo, T.; Fukushi, H.; Matsumura, T. Pathogenicity and immunogenicity of equine herpesvirus type 1 mutants defective in either $\mathrm{gI}$ or $\mathrm{gE}$ gene in murine and hamster models. J. Vet. Medic. Sci. 2006, 68, 1029_ 1038 .

[28] Fukushi, H.; Taniguchi, A.; Yasuda, K.; Yanai, T.; Masegi, T.; Yamaguchi, T.; Hirai, K. A hamster model of equine herpesvirus 9 induced encephalitis. J. Neuro. Virol. 2000, 6, 314-319.

[29] El-Habashi, N.; El-Nahass, E.; Fukushi, H.; Hibi, D.; Sakai, H.; Sasseville, V.; Yanai, T. Experimental intranasal infection of equine herpesvirus 9 (EHV-9) in suckling hamsters: Kinetics of viral transmission and inflammation in the nasal cavity and brain. J. Neuro. Virol. 2010, 16, 242-248; DOI: $10.3109 / 13550284.2010 .489596$. 
[30] El-Habashi, N.; Murakami, M.; El-Nahass, E.; Hibi, D.; Sakai, H.; Fukushi, H.; Sasseville, V.; Yanai, T. Study on the infectivity of Equine Herpesvirus 9 (EHV-9) by different routes of inoculation in hamsters. Vet. Path. 2011, 47, 1-7; DOI: $10.1177 / 0300985810375053$.

[31] El-Nahass, E.; El-Habashi, N.; Abdelaziz, A. A.; Nayel, M.; Kasem, S.; Fukushi, H.; Tuji, H.; Hirata, A.; Sakai, H.; Yanai, $\mathrm{T}$. Kinetics and pathogenicity of oral infection by Equine Herpesvirus-9 in mice and suckling hamsters. J. Comp. Path. 2012, 146, 211-222; DOI: 10.1016/j.jcpa.2011.05.003.

[32] Mesquita, L. P.; Arévalo, A. F.; Zanatto, D. A.; Miyashiro, S. I.; Cunha, E. M. S.; Souza, M. C. C.; Villalobos, E. M. C.; Mori, C. M. C.; Maiorka, P. C.; Mori, E. Equine herpesvirus type 1 induces both neurological and respiratory disease in Syrian hamsters. Vet. Microbio. 2017, 203, 117-124; DOI: http://dx.doi.org/10.1016/j.vetmic.2017.03.007.

[33] Pagamjav, O.; Sakata, T.; Matsumura, T.; Yamaguchi, T.; Fukushi, H. Natural recombinant between equine herpesviruses 1 and 4 in the ICP4 gene. Microbiol. Immunol. 2005, 49, 167-179.

[34] Nugent, J.; Birch-Machin, I.; Smith, K. C.; Mumford, J. A.; Swann, Z.; Newton, J. R.; Bowden, R. J.; Allen, G. P.; Davis-Poynter, N. Analysis of Equid Herpesvirus 1 strain variation reveals a point mutation of the DNA polymerase strongly associated with neuropathogenic versus non-neuropathogenic disease outbreaks. J. Virol. 2006, 80, 4047-4060; DOI: 10.1128/JVI.80.8.4047-4060.2006.

[35] Goodman, L. B.; Loregian, A.; Perkins, G. A.; Nugent, J.; Buckles, E. L.; Mercorelli, B.; Kydd, J. H.; Palù, G.; Smith, K. C.; Osterrieder, N.; Davis-Poynter, N. A point mutation in a herpesvirus polymerase determines neuropathogenicity. PLoS Pathog. 2007, 11, 1583-1592; DOI: 10.1371/journal.ppat.0030160.

[36] Abo-Sakaya, R.; Ebeid, M. H.; Galila, E. M.; Nayel, M.; Kasem, S.; Abdelwahab, M. G.; Moustafa, A. M.; Arnaout, F. K.; Fukushi, H. D/N752 coding change in DNA polymerase gene (ORF30) plays no role in equid herpesvirus type $1(\mathrm{EHV}-1)$ growth in vitro. Benha Vet. Med. J. 2014, 26, 1-9.

[37] Kasem, S.; Yu, M. H. H.; Yamada, S.; Kodaira, A.; Matsumura, T.; Tsujimura, K.; Madbouly, H.; Yamaguchi, T.; Ohya, K.; Fukushi, H. The ORF37 (UL24) is a neuropathogenicity determinant of equine herpesvirus 1 (EHV-1) in the mouse encephalitis model. Virology. 2010, 400, 259-270; DOI: 10.1016/j.virol.2010.02.012

[38] Carvalho, R. F.; Oliveira, A. M.; Souza, A. M.; Passos, L. M.; Martins, A. S. Prevalence of equine herpesvirus type 1 latency detected by polymerase chain reaction. Arch. Virol. 2000, 145, 1773-1787.

[39] Galosi, C. M.; Echeverria, M. G.; Vila Roza, M. V.; Cid De LaPaz, V.; Oliva, G. A.; Etcheverrigaray, M. E. Virus herpes eqüino tipo 1 (EHV-1): patrones de restricción de $\mathrm{ADN}$, perfiles protéicos y estúdios de patogenicidad em ratones. Analecta Vet. 1998, 18, 35-40.

[40] Martín Ocampo, G. P.; Barbeito, C. G.; Galosi, C. M. Genomic Studies and genetic characterization of equid herpesvirus type 1 (EHV-1) strains: estimating the global similarity by distance methods. Int. Res. J. Microbiol. 2011, 2, 079-084.

[41] Crabb, B. S.; Studdert, M. J. Equine herpesvirus 4 (equine rhinopneumonitis virus) and 1 (equine abortation virus). $A d v$.
Virus Res.1995, 45, 135-190.

[42] Allen, G. P. Epidemic disease caused by equine herpesvirus-1:recommendations for prevention and control. Equ.Vet. Educ. 2002, 14, 136-142.

[43] Costa, E. A.; Lima, G. B. L.; Castro, R. T.; Furtini, R.; Portilho, R. V.; Resende, M. Meningo encephalitis in a horse associated with equine herpesvirus 1. Arq. Bras. Med. Vet. Zootec. 2008, $60,1580-1583$.

[44] Pusterla, N.; Hussey, G. S. Equine herpesvirus 1 myeloencephalopathy. Vet. Clin. North Am. Equine Pract. 2014, 30, 489-506; DOI: 10.1016/j.cveq.2014.08.006.

[45] El-Nahass, E.; El-Dakhly, K. M.; El-Habashi, N.; Anwar, S. I.; Sakai, H.; Hirata, A.; Okada, A.; Abo-Sakaya, R.; Fukushi, H.; Yanai, T. Susceptibility of BALB/c-nu/nu mice and BALB/c mice to Equine Herpesvirus 9 infection. Vet. Pathol. 2014, 51, 581-590; DOI: 10.1177/0300985813493932.

[46] Eöry, M. L.; Zanuzzi, C. N.; Fuentealba, N. A.; Sguazza, G. H.; Gimeno, E. J.; Galosi, C. M.; Barbeito, C. G. Effects of different anesthetics in the murine model of EHV-1 infection. Vet. Pathol. 2013, 5, 849-856; DOI: $10.1177 / 0300985813476062$.

[47] Allen, G. P.; Timoney, P. J. Recent advances in our understanding of equine herpesvirus-1 (EHV-1) myeloencephalopathy. In: $107^{\text {th }}$ Annual Meeting of the United States Animal Health Association, 2007, 373-380.

[48] Franz, M.; Goodman, L. B.; VandeWalle, G. R.; Osterrieder, N.; Greenwood, A. D. A Point Mutation in a Herpesvirus Co-Determines Neuropathogenicity and Viral Shedding. Viruses. 2017, 9, 1-7; DOI: 10.3390/v9010006.

[49] Mori, E.; Lara, M. C. C. S. H.; Cunha, E. M. S.; Villalobos, E. M. C.; Mori, C. M. C.; Soares, R. M.; Brandão, P. E.; Fernandes, W. R.; Richtzenhain, L. J. Molecular characterization of Brazilian equid herpesvirus type 1 strains based on neuropathogenicity markers. Braz. J. Microbiol. 2015, 46, 565-570; DOI: 10.1590/S1517-838246220140096.

[50] Cymerys, J.; Słońska, A.; Brzezicka, J.; Tucholska, A.; Chmielewska, A.; Rola, J.; Malik, P.; Bańbura, M. W. Replication kinetics of neuropathogenic and non-neuropathogenic equine herpesvirus type1 (EHV-1) strains in primary murine neurons and ED cell line. Polish. Jour. Vet. Scien. 2016, 4, 777-784; DOI: 10.1515/pjvs-2016-0098.

[51] Perkins, G. A.; Goodman, L. B.; Tsujimura, K.; VandeWalle, G. R.; Kim, S. G.; Dubovi, E. J.; Osterrieder, N. Investigation of the prevalence of neurologic equine herpesvirus type 1 (EHV-1) in a 23-year retrospective analysis (1984-2007). Vet. Microbiol. 2009, 139, 375-378; DOI: 10.1016/j.vetmic.2009.06.033.

[52] Pronost, S.; Léon, A.; Legrand, L.; Fortier, C.; Miszczak, F.; Freymuth, F.; Fortier, G. Neuropathogenic and non-neuropathogenic variants of equine herpesvirus 1 in France. Vet. Microbiol. 2010, 145, 329-33. DOI: 10.1016/j.vetmic.2010.03.031.

[53] Hussey, G. S.; Ashton, L. V.; Quintana, A. M.; VandeWalle, G. R.; Osterrieder, N.; Lunn, D. P. Equine herpesvirus type 1 pUL56 modulates innate responses of airway epithelial cells. Virology. 2014, 464-465, 76-86; DOI: 10.1016/j.virol.2014.05.023. 
[54] Holz, C. L.; Nelli, R. K.; Wilson, M. E.; Zarski, L. M.; Azab, W.; Baumgardner, R.; Osterrieder, N.; Pease, A.; Zhang, L.; Hession, S.; Goehring, L. S.; Hussey, S. B.; Hussey, G. S. Viral genes and cellular markers associated with neurological complications during herpesvirus infections. J. Gen. Virol. 2017, 6, 1439-1454; DOI: 10.1099/jgv.0.000773.
[55] Oladunni, F. S.; Sarkar, S.; Reedy, S.; Balasuriya, U. B. R.; Horohov, D. W.; Chambers, T. M. Absence of relationship between type-I interferon suppression and neuropathogenicity of EHV-1. Vet. Immunol. Immunopathol. 2018, 197, 24-30; DOI: 10.1016/j.vetimm.2018.01.007. 